\title{
ANALISIS FINANSIAL HASIL HUTAN KAYU Acacia mangium DI KPH BOGOR
}

\author{
(Financial Analysis of Acacia mangium Wood Forest In Bogor KPH) \\ Ika Lestari Hutasuhut ${ }^{1}$ \\ $\left.{ }^{1}\right)$ Staff Pengajar Fakultas Kehutanan Universitas Lancang Kuning \\ Jln. Yos Sudarso Km. 8 Rumbai Pekanbaru Riau \\ Email: lestariika32@gmail.com
}

Diterima: 24 April 2019, Direvisi: 01 Juli 2019 , Disetujui: 10 Junli 2019

DOI: https://doi.org/10.31849/forestra

\begin{abstract}
Acacia mangium is one of popular plantion in industrial forest of Indonesia. Perum Perhutani is one of state owned enterprise in Indonesia was also manage Acacia mangium in KPH Bogor. Forest management is always related to investment made by the company, so it was necessesary to analysist of business. Financial analysis is the process of evaluating business to determine their performence and suitability. Typically, financial analyze is used to analyze whether an entity is stable to warrant investment. The method used in this study is financial analysist based on Acacia mangium forest product. This study is conducted to find out whether KPH Bogor has good financial condition or not. The results of the study showed that KPH Bogor has good financial condition, feasible in running business, and provided benefits to the company. The NPV, BCR, IRR values are IDR 377.690.545, 3,96 and 25,02\% respectively. KPH Bogor also capable survive if there decreasing of production volume with $5 \%, 10 \%$ and $15 \%$ respectively.
\end{abstract}

Keywords: Acacia mangium, financial analysist, sensitivity analysis, KPH Bogor

\begin{abstract}
ABSTRAK
Acacia mangium adalah salah satu tanaman cukup terkenal di hutan tanaman industri di Indonesia dan banyak dikelola oleh berbagai perusahaan kehutanan. Salah satu diantaranya Perum Perhutani yang merupakan salah satu badan usaha milik negara di Indonesia, mengelola tanaman Acacia mangium di salah satu unit pengelolaanya yang berada di KPH Bogor. Pengelolaan hutan selalu berkaitan dengan investasi yang dilakukan oleh perusahaan, sehingga diperlukan analisis finansial. Analisis finansial adalah proses mengevaluasi suatu usaha apakah suatu usaha layah dijalankan atau tidak, dengan melihat penerimaan dan pengeluaran. Metode yang digunakan dalam penelitian ini adalah analisis finansial berdasarkan hasil hutan Acacia mangium. Penelitian ini bertujuan untuk menganalisis pengelolaan hutan di KPH Bogor dengan menggunakan analisis finansial. Hasil penelitian menunjukkan bahwa KPH Bogor memiliki kondisi keuangan yang baik dan layak dijalankan, serta memberikan manfaat bagi perusahaan. Nilai NPV, BCR, IRR masing-masing adalah Rp. 377.690.545, 3,96 dan 25,02\%. Berdasarkan analisis sensitivitas dengan menggunakan faktor penurunan produksi kayu (volume) sebesar 5\%, 10\% dan 15\%, menunjukkan bahwa KPH Bogor mampu bertahan dengan adanya penurunan volume produksi. Nilai NPV, BCR dan IRR masing-masing masih bernilai positif.
\end{abstract}

Kata kunci : Acacia mangium. analisis finansial, analisis sentivitas, KPH Bogor 


\section{PENDAHULUAN}

Acacia mangium merupakan salah satu jenis pohon yang cepat tumbuh dan paling umum digunakan untuk pengembangan hutan tanaman. Tanaman ini juga memiliki keunggulan dengan pertumbuhan pohon yang cepat, kualitas kayu yang bagus dan tahan diberbagai jenis lingkungan hidup (Krisnawati et al. 2011). Jenis pohon ini banyak dikembangkan di hutan tanaman industri Indonesia sebagai salah satu bahan baku olahan hasil hutan. Pengelolaan jenis pohon ini menuntut perusahaan-perusahaan harus mampu untuk mengelola dan memprediksi hasil akhir daur yang maksimal. Perum Perhutani sebagai salah satu badan usaha milik negara juga turut serta mengelola jenis pohon ini disalah satu kelas perusahaan di KPH Bogor.

KPH Bogor merupakan unit manajemen dari Divisi Regional III Jawa Barat dan Banten yang berkantor pusat di Cibinong, kabupaten Bogor. KPH Bogor memiliki 4 bagian unit pengelolaan yang disebut Bagian Kesatuan Pemangku Hutan (BKPH) yang terdiri dari BKPH Parung Panjang, BKPH Leuwiliang, BKPH Bogor dan BKPH Tanggerang. Salah satu BKPH yang ditetapkan untuk kelas perusahaan hutan tanaman kayu Acacia mangium adalah BKPH Parung Panjang. Tujuan utama kelas perusahaan kayu ini adalah untuk kayu pertukangan dengan daur 8 tahun dan sistem silvikultur tebang habis permudaan buatan. Luas BKPH ini ditetapkan seluas 5342.90 Ha, yang terbagi di 3 Resort Pemangkuan Hutan (RPH) yakni RPH Jagabaya, RPH Maribaya dan RPH Tenjo.

Usaha pembangunan hutan selalu berkaitan dengan investasi yang harus dikeluarkan oleh perusahaan, sehingga perlu dilakukan analisis pada usaha atau proyek tersebut. Analisis usaha ini juga digunakan sebagai prediksi, apakah hasil akhir usaha lebih besar dari investasi. Salah satu analisis yang banyak dilakukan untuk menduga hasil usaha hutan adalah analisis finansial, karena analisis ini cocok untuk usaha jangka panjang, usaha yang memiliki aliran arus kas (cash flow) output-input dan usaha yang mengandung risiko terhadap suku bunga (Nugroho 2004). Analisis finansial merupakan penilaian suatu usaha untuk menentukan apakah suatu usaha dapat dijalankan atau tidak dengan melihat apakah penerimaan lebih besar dari pengorbanan yang dilakukan (Riyanto 2012).

Penelitian yang dilakukan di $\mathrm{KPH}$ Bogor ini bertujuan untuk menyusun analisis kelayakan hutan tanaman kayu Acacia mangium untuk tahun tanam 2018-2026 dengan menggunakan referensi data 20092017. Analisis kelayakan yang dilakukan berdasarkan tiga kriteria investasi yakni net present value (NPV), benefit cost ratio (BCR), dan internal rate of return (IRR) (Gray, Simanjuntak, Sabur, Maspaitella, \& Varley, 2007) selama umur usaha 8 tahun. Hasil penelitian ini juga diharapkan dapat digunakan sebagai bahan pertimbangan utuk KPH Bogor dalam melakukan pengelolaan tanaman Acacia mangium untuk daur selanjutnya.

\section{METODE PENELITIAN}

Penelitian ini dilaksanakan di $\mathrm{KPH}$ Bogor, Perum Perhutani Divisi Regional III Jawa Barat dan Banten yang dilaksanakan pada bulan November 2017 sampai dengan Januari 2018.

\subsection{Jenis Data}

Penelitian ini menggunakan dua jenis data yaitu data primer dan sekunder. Data primer meliputi data hasil wawancara yang 


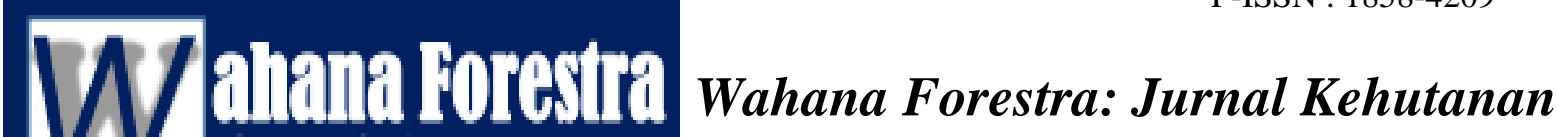 gutnal Kehutanan}

diperoleh dari informan yaitu staf produksi dan staf keuangan yang dipilih di $\mathrm{KPH}$ Bogor. Sedangkan data sekunder meliputi data yang diperoleh dari instansi terkait yang sifatnya mendukung penelitian (Lapau 2013) yakni data laporan divisi persemaian, penanaman, pemeliharaan, penjarangan, penebangan, dokumen rencana pengaturan kelas perusahaan Acacia Mangium di $\mathrm{KPH}$ Bogor, laporan inventarisasi, laporan kuangan dan tarif upah KPH Bogor.

\subsection{Analisis Finansial}

Penggunaan metode analisis finansial pada penelitian ini bertujuan untuk mengetahui kondisi finansial perusahaan, oleh sebab itu dilakukan beberapa asumsiasumsi dalam metode analisis finansial ini, yakni:

1. Kelas perusahaan yang digunakan pada penelitian ini adalah hasil hutan kayu Acacia mangium, dengan daur (8 tahun) yang berada pada Bagian Pemangku Hutan (BKPH) di Parung Panjang. Menggunakan simulasi perhitungan analisis finansial 20182026, dengan referensi data tanaman 2009-2017 di BKPH Parung Panjang.

2. Luas total areal adalah $752,66 \mathrm{Ha}$, dengan luas areal produktif yang digunakan 677,4 Ha (dikurangi 10\% untuk areal non-produksi).

3. Model pengelolaan mengikuti Hutan Tanaman Industri (HTI), yang dibagi ke dalam 8 blok dengan luas 84,67 Ha pada masing-masing blok.

4. Sistem silvikultur yang diterapkan di perusahaan adalah sistem silvikultur tebang habis permudaan buatan.

5. Adanya ketidakpastian yang terjadi dalam pembangunan hutan tanaman yang berkaitan dengan faktor alam seperti banjir, hama dan penyakit, kebakaran dan lain-lain. Sehingga asumsi gangguan terhadap hutan berupa hama dan penyakit, pencurian kayu, kebakaran dan bencana alam lainnya masih bisa dikendalikan (Yuniati 2011).

6. Produksi pada akhir daur semuanya diserap pasar.

7. Suku bunga yang digunakan dalam penelitian ini adalah 10\%, disesuaikan dengan suku bunga pinjaman di bank.

Metode analisis finansial menggunakan tiga kriteria investasi yakni net present value (NPV), benefit cost ratio (BCR), dan internal rate of return (IRR) (Gray et al., 2007). NPV merupakan manfaat bersih yang diterima selama usaha berlangsung pada tingkat diskonto tertentu dan merupakan selisih antara nilai sekarang arus manfaat dikurangi dengan nilai sekarang arus biaya. BCR adalah perbandingan manfaat (benefit) dengan total biaya yang telah dikeluarkan dalam suatu usaha. IRR digunakan untuk menentukan apakah investasi layak dilaksanakan atau tidak dengan melihat apakah hasil suku bunga perhitungan lebih tinggi dibandingkan suka bunga yang digunakan. Dibawah ini rumus NPV, BCR dan IRR yang digunakan:

\section{A. Net Present Value (NPV)}

Rumus yang digunakan adalah:

$$
\mathrm{NPV}=\sum_{\mathrm{t}=0}^{\mathrm{n}} \frac{B t-C t}{(1+i)^{t}}
$$

Keterangan:

$$
\begin{aligned}
\mathrm{Bt}= & \text { Benefit } \text { (penerimaan usaha } \\
& \text { pada tahun ke- } \mathrm{t} \text { ) } \\
\mathrm{Ct}= & \text { Cost (biaya usaha pada tahun } \\
& \text { ke- } \mathrm{t}) \\
\mathrm{n}= & \text { umur ekonomis proyek }
\end{aligned}
$$




$$
\text { i = tingkat suku bunga yang }
$$

Suatu usaha dikatakan layak untuk dilakukan bila menghasilkan NPV $>0$. Bila $\mathrm{NPV} \leq 0$, maka usaha tersebut tidak layak untuk dijalankan.

\section{B. Benefit Cost Ratio (BCR)}

Rumusan yang digunakan adalah:

$$
\text { Net } B / C=\frac{\sum_{t=1}^{n} \frac{B t-C t}{(1+i)^{t}}}{\sum_{t=1}^{n} \frac{C t-B t}{(1+i)^{t}}}
$$

Keterangan:

$$
\begin{aligned}
\mathrm{Bt}= & \text { Benefit } \text { (penerimaan usaha } \\
& \text { pada tahun ke- } \mathrm{t} \text { ) } \\
\mathrm{Ct}= & \text { Cost } \text { (biaya usaha pada tahun } \\
& \text { ke- } \mathrm{t}) \\
\mathrm{n}= & \text { umur ekonomis proyek } \\
\mathrm{i} \quad & \text { tingkat suku bunga yang } \\
& \text { berlaku }
\end{aligned}
$$

Kriteria yang dapat diperoleh dari penghitungan $\mathrm{Net} B / \mathrm{C}$ antara lain:

Net $B / C>1$, maka usaha menguntungkan;

Net $\quad B / C=1$, maka usaha tidak menguntungkan dan tidak merugikan;

Net $B / C<1$, maka usaha merugikan.

\section{Internal Rate of Return (IRR)}

IRR dirumuskan sebagai berikut:

$$
I R R=i_{1}+\frac{N P V_{1}}{N P V_{1}-N P V_{2}}\left(i_{2}-i_{1}\right)
$$

\section{Keterangan:}

NPV1 = NPV yang bernilai positif

NPV2 = NPV yang bernilai negatif

$$
\begin{aligned}
i_{1} \quad= & \text { tingkat suku bunga saat } \\
& \text { menghasilkan NPV yang } \\
& \text { bernilai positif }
\end{aligned}
$$

\author{
$i_{2} \quad=$ tingkat suku bunga saat \\ menghasilkan NPV yang \\ bernilai negatif
}

Suatu proyek akan dipilih bila nilai IRR yang dihasilkan lebih tinggi dari pada tingkat suku bunga yang berlaku (IRR > social discount rate). Bila IRR < social discount rate menunjukkan bahwa modal proyek akan lebih menguntungkan bila didepositokan di bank dibandingkan bila digunakan untuk menjalankan usaha.

\subsection{Ananlisis Sensitivitas}

Analisis sensitivitas merupakan suatu analisis yang digunakan untuk melihat pengaruh akibat dari perencanaan dan keadaan yang berubah-ubah. Tujuan analisis sensitivitas untuk melihat suatu kegiatan usaha apabila terjadi perubahan bagaimana pengaruhnya terhadap perhitungan biaya dan manfaat (kekuatan usaha), serta mengetahui sejauh mana keputusan mampu berhadapan dengan faktor-faktor pengubah (Sufa 2007). Penilaian biaya dan manfaat untuk suatu usaha tidak terlepas dari masa depan, perkiraan nilai sekarang dan masa depan dipengaruhi oleh ketidakpastian (Gregersen 1979). Menurut Gregersen (1979) pada usaha kehutanan beberapa faktor-faktor yang memungkinkan terjadinya ketidakpastian yakni:

a. Faktor alam, seperti bencana alam, serangan hama penyakit, kebakaran dan sebagainya.

b. Faktor teknologi dan produktivitas yang berhubungan dengan proses produksi, misalnya teknik silvikultur, peralatan dan mesin.

c. Faktor finansial dan ekonomi, misalnya pengaruh kenaikan dan penurunan harga input dan output pada proses produksi. 
d. Faktor manusia, misalnya ketidaktepatan dalam menduga hasil produksi (taksiran volume) dan keadaan pasar.

Pada penelitian ini faktor analisis sensitivitas yang digunakan untuk melihat sejauh mana kekuatan usaha berjalan adalah faktor manusia memperkirakan kejadiankejadian mendatang mengenai taksiran volume kayu pada awal perencanaan dengan hasil produksi akhir. Asumsi yang digunakan adalah bagaimana kemampuan finansial $\mathrm{KPH}$ Bogor apabila terjadi penurunan taksiran volume sebesar 5\%, 10\% dan $15 \%$.

\section{HASIL DAN PEMBAHASAN}

Luas areal yang digunakan peneliti dalam menghitung analisis finansial ini adalah $752.66 \mathrm{Ha}$ untuk tanaman dengan menggunakan referensi data yang diproduksi tahun 2009 dan ditebang tahun 2017 di KPH Bogor. Perhitungan analisis finansial yang dilakukan dalam penelitian ini menggunakan model pengelolaan Hutan Tanaman Industri (HTI) dengan membagi luas ke dalam blok maksimal yang disesuaikan dengan daur. Luas areal efektif untuk kegiatan produksi adalah 677.4 Ha dengan luas areal nonproduksi 75.266 ha $(10 \%$ dari luas total areal) di bagi ke dalam 8 blok dengan luas blok masing-masing $84.67 \mathrm{Ha}$.

\section{a. Komponen biaya}

Komponen biaya pengusahaan hutan ini dimulai dari kegiatan persemaian hingga tegakan siap panen dalam satuan hektare (Ha) yang disebut dengan biaya produksi. Komponen biaya lain seperti biaya bangunan, biaya sarana prasarana dan biaya umum lainnya tidak dimasukkan dalam perhitungan. Hal ini dianggap perusahaan sudah berjalan cukup lama, sehingga biayabiaya tersebut sudah tertutupi. Pengeluaran dan pendapatan kayu hasil penjarangan pada tahun ke-3 dan ke-5 tidak dimasukkan dalam perhitungan, karena hasil penjarangan tahun ke-3 merupakan sistem bagi hasil dengan Lembaga Masyarakat Desa Hutan (LMDH) yang merupakan mitra kerja Perhutani. Hasil penjarangan pada tahun ke-5 dianggap hanya bisa menutupi biaya penjarangan itu sendiri, sehingga penerimaan dan pengeluaran dianggap tidak ada. Tabel 1 dibawah ini merupakan tabel komponen biaya dalam pengusahaan hutan tanaman Acacia mangium. Tabel ini menjelaskan jumlah biaya produksi yang dikeluarkan berdasarkan kegiatan di setiap blok dalam satuan ha. Kegiatan persemaian, penanaman dan pemeliharaan pertama dilakukan di tahun ke-1, pemeliharaan kedua dilakukan di tahun ke-2, penjarangan dan pemangkasan cabang dilakukan di tahun ke-3 dan penjarangan lanjutan di tahun ke-5. Semua kegiatan dilaksanakan sesuai dengan tahun berjalannya daur di masing-masing blok.

Tabel 1. Komponen biaya kegiatan produksi tanaman Acacia mangium

\begin{tabular}{|c|l|c|}
\hline No. & \multicolumn{1}{|c|}{$\begin{array}{c}\text { Komponen biaya } \\
\text { produksi }\end{array}$} & $\begin{array}{c}\text { Biaya } \\
(\mathbf{R p} / \mathbf{H a})\end{array}$ \\
\hline 1 & Persemaian & 3.330 .000 \\
\hline 2 & Penanaman & 6.643 .271 \\
\hline 3 & Pemeliharaan 1 & 2.250 .000 \\
\hline 4 & Pemeliharaan 2 & 2.290 .000 \\
\hline 5 & $\begin{array}{l}\text { Pemeliharaan tahun ke-3 } \\
\text { (penjarangan dan } \\
\text { pemangkasan cabang) }\end{array}$ & - \\
\hline 6 & $\begin{array}{l}\text { Pemeliharaan tahun ke-5 } \\
\text { (penjarangan lanjutan) }\end{array}$ & - \\
\hline 7 & Penebangan & 19.185 .000 \\
\hline 8 & Gaji karyawan & 450.000 \\
\hline
\end{tabular}




\section{b. Harga kayu dan pendapatan}

Harga kayu yang digunakan dalam perhitungan analisis finansial ini adalah harga kayu yang sudah berada di Tempat Pengumpulan Kayu (TPK). Harga kayu di TPK cenderung lebih tinggi jika dibandingkan harga kayu masih di area penebangan. Adanya tahap pengujian kayu membuat kayu memiliki kualitas sortimen yang lebih baik dan meningkatkan harga jual kayu. Sortimen kayu yang sudah berada di TPK dibagi menjadi tiga kelas diameter yakni AI (10-19 cm), AII $(20-29 \mathrm{~cm}$ dan AIII $(>30 \mathrm{~cm})$ dengan panjang sortimen yang sama yakni dua meter. Perbedaan kelas diameter kayu tentu mempengaruhi harga kayu dalam satuan $\mathrm{Rp} / \mathrm{m}^{3}$, oleh sebab itu penting mengetahui proporsi jumlah kayu berdasarkan kelas diameter dalam satuan hektare. Dalam satuan hektare diduga bahwa kelas diameter AI memiliki proporsi 20\%, AII $75 \%$ lebih mendominasi dan sisanya $5 \%$ pada kelas diameter AIII. Kelas diameter AII adalah kelas diameter rata-rata kayu fast growing termasuk salah satunya Acacia mangium, selain itu kelas diameter AII juga diperuntukkan untuk kayu pertukangan. Tabel 2 dibawah ini menjelaskan harga kayu berdasarkan kelas diameter dan proporsi sortimen kayu.

Tabel 2. Harga kayu berdasarkan sortimen

\begin{tabular}{ccr}
\hline No. & Jenis kayu bulat & \multicolumn{1}{c}{ Harga $\left(\mathbf{R p} / \mathbf{m}^{\mathbf{3}}\right)$} \\
\hline 1 & AI & 680.500 \\
2 & AII & 880.000 \\
3 & AIII & 1110.000 \\
\hline
\end{tabular}

Pendapatan diperoleh dari hasil perkalian taksiran volume akhir daur dengan harga kayu di TPK. Taksiran volume/ha kayu Acacia mangium diperoleh sebesar $242,5 \mathrm{~m}^{3} /$ ha yang diperoleh dari tabel tarif volume di KPH Bogor. Sehingga pendapatan kayu dihitung dengan menggunakan asumsi sebagai berikut:

Jumlah AI $\left(\mathrm{m}^{3}\right)$

$=\left(242,5 \mathrm{~m}^{3} / \mathrm{ha} \times 20 \%\right) \times$ Rp. 680.5000

$=$ Rp. 29.512.250/ha

Jumlah AII $\left(\mathrm{m}^{3}\right)$

$=\left(242,5 \mathrm{~m}^{3} / \mathrm{ha} \times 75 \%\right) \times \mathrm{Rp} .880 .000$

$=$ Rp. 160.050.000/ha

Jumlah AIII $\left(\mathrm{m}^{3}\right)$

$=\left(242,5 \mathrm{~m}^{3} / \mathrm{ha} \times 5 \%\right) \times$ Rp. 1.110 .000

$=$ Rp. 13.458.750/ha

Sehingga total pendapatan kayu diperoleh dari hasil penjumlahan (AI+AII+AIII), diperoleh Rp. 203.021.000/ha di akhir daur.

\section{c. Analisis finansial (NPV, BCR dan IRR)}

Kriteria penilaian yang digunakan dalam penelitian ini adalah net present value (NPV), benefit cost ratio (BCR) dan internal rate of return (IRR). Pada analisis finansial menggunakan suku bunga (faktor diskonto) sebesar $10 \%$ yang merupakan suku bunga pinjaman bank. Penggunaan suku bunga pinjaman ini digunakan karena apabila suatu dana dipinjam maka asumsi penggunaannya adalah untuk investasi ke dalam suatu usaha. Hasil perhitungan nilai NPV, BCR dan IRR hasil hutan kayu Acacia mangium dapat dilihat pada Tabel 3 dibawah ini.

Tabel 3. Hasil perhitungan NPV, BCR dan IRR dalam analisis finansial Acacia mangium

\begin{tabular}{lr} 
Kriteria Penilaian & \multicolumn{1}{c}{ Nilai } \\
\hline Net present value $(N P V)$ & Rp. 377.690 .545 \\
$\begin{array}{l}\text { Benefit cost ratio }(B C R) \\
\text { Internal rate of return }\end{array}$ & 3,96 \\
(IRR) & $25,02 \%$ \\
\hline
\end{tabular}



Vol. 14 No. 1 Januari 2019

Berdasarkan 3 kriteria penilaian analisis finansial yakni menggunakan NPV, BCR dan IRR. Diperoleh NPV Rp. 377.690.545, sedangkan BCR 3,96 dan IRR sebesar 25,02\%. Dari ketiga kriteria penilaian diatas dapat disimpulkan bahwa usaha tanaman Acacia mangium tahun produksi 2018-2026 merupakan usaha yang layak untuk dijalankan. Secara finansial memberikan keuntungan serta manfaat bagi perusahaan hal ini dilihat dari besarnya nilai NPV > 0. Besarnya NPV yang diperoleh perusahaan juga dibuktikan dengan nilai rasio antara biaya dan pendapatan $(\mathrm{B} / \mathrm{C})>1$ artinya setiap pengeluaran Rp. 1 memberi menghasilkan manfaat sebesar Rp. 3,96. Untuk melihat sejauh mana usaha tersebut layak untuk dijalankan, maka tingkat suku bunga yang diperoleh dari hasil perhitungan harus lebih besar dari tingkat suku bunga yang digunakan. Nilai IRR yang diperoleh dari hasil perhitungan analisis finansial adalah $25,02 \%$, lebih besar dari suku bunga yang digunakan sebesar $10 \%$, artinya usaha layak dijalankan dan menguntungkan dengan tingkat pengembalian modal $25,02 \%$.

\section{d. Analisis Sensitivitas}

Analisis sensitivitas dilakukan untuk menguji kekuatan usaha dengan menggunakan faktor ketidakpastian (faktor manusia) dalam penaksiran volume. Analisis sensitivitas menggunakan asumsi adanya penurunan produksi kayu akhir daur turun $5 \%, 10 \%$ dan $15 \%$ dari taksiran volume sebelumnya. Hasil analisis sensitivitas menggunakan asumsi tersebut menunjukkan bahwa usaha hasil hutan kayu Acacia mangium 2018-2026 cukup kuat dalam menghadapi perubahan-perubahan ketidakpastian tersebut. Hasil analisis sensitivitas dapat dilihat pada Tabel 4 dibawah ini.

\begin{tabular}{ccrr} 
Tabel 4. & \multicolumn{4}{c}{$\begin{array}{l}\text { Nilai NPV, IRR dan BCR ketika } \\
\text { terjadi } \\
\text { volume }\end{array}$} & & \\
\hline penurunan & taksiran \\
\hline Taksiran & NPV (Rp) & BCR & IRR (\%) \\
\hline $5 \%$ & 333.687 .497 & 3,59 & 23,21 \\
$10 \%$ & 282.290 .904 & 3,19 & 21,15 \\
$15 \%$ & 230.894 .312 & 2,79 & 18,82 \\
\hline
\end{tabular}

Berdasarkan nilai NPV, BCR dan IRR pada Tabel 4 menunjukkan bahwa usaha tersebut masih layak dijalankan dengan adanya perubahan-perubahan yang terjadi akibat ketidakpastian. Nilai NPV secara berturut-turut baik pada penurunan taksiran volume 5\%, 10\% dan 15\% masih memberi keuntungan sebesar Rp. 333.540.747, Rp. 282.144.154 dan Rp. 230.747.561 lebih besar dari nol (NPV>0), artinya. Sedangkan nilai BCR lebih besar dari satu $(B / C>1)$ yang artinya setiap pengeluaran $\mathrm{Rp}$. 1 memberi menghasilkan manfaat sebesar Rp. 3,59 Rp. 3,19 dan Rp. 2,79. Dan nilai IRR yang diperoleh lebih besar dari suku bunga yang digunakan (10\%), secara finansial usaha ini menguntungkan dan layak diusahakan. Dengan tingkat pengembalian modal sebesar $23,21 \%, 21,15 \%$ dan $18,82 \%$. Hasil analisis dapat disimpulkan bahwa penurunan taksiran volume sebesar 5\%, 10\% dan $15 \%$ pada akhir produksi membuat usaha hasil hutan kayu Acacia mangium tahun 2018-2026 cukup kuat dalam menghadapi perubahan-perubahan yang terjadi. 

Vol. 14 No. 1 Januari 2019

IV. KESIMPULAN

Hasil analisis finansial KPH Bogor menggunakan kelas perusahaan Acacia mangium merupakan usaha yang layak dan memberikan keuntungan. Nilai NPV Rp. 377.690.545, BCR 3,96 dan IRR 25,02\%. Hasil ini menunjukkan bahwa kelas perusahaan kayu Acacia mangium di KPH Bogor layak untuk dijalankan pada daur selanjutnya. Adapun perubahan-perubahan yang terjadi selama proses pembangnan hutan berlangsung masih bisa diatasi. Hasil analisis sensitivitas dapat membuktikan bahwa penurunan taksiran volume sebesar $5 \%, 10 \%$ dan $15 \%$ pada akhir produksi membuat usaha hasil hutan kayu Acacia mangium tahun 2018-2026 cukup kuat dalam menghadapi perubahan-perubahan yang terjadi.

\section{UCAPAN TERIMAKASIH}

Ucapan terimakasih penulis sampaikan kepada JSPS-DGHE DIKTI atas bantuan pendanaan dalam pelaksanaan penelitian ini. Penulis juga mengucapkan terimakasih sebesar-besarnya kepada Dr. Efi Yuliati Yovi selaku ketua peneliti atas kesempatan yang diberikan untuk bergabung dalam penelitian ini. Semoga hasil penelitian ini memberikan kontribusi untuk kemajuan ilmu dan teknologi, khususnya dibidang kehutanan.

\section{DAFTAR PUSTAKA}

Gray, C., Simanjuntak, P., Sabur, L. K., Maspaitella, P. F. L., \& Varley, R. C. G. (2007). Pengantar Evaluasi Proyek. In PT Gramedia Pustaka Utama. Retrieved from

\author{
https://books.google.co.id/books/about/ \\ Pengantar_Evaluasi_Proyek_Ed2.html? \\ hl=id\&id=KlsYdLc7EEkC\&redir_esc $=$ \\ $\mathrm{y}$
}

Gregersen, Hans M. 1979. Economic analysis of forestry project. Food and agriculture organization of the united nations: Rome.

Lapau, Buchari. 2013. Metode penelitian kesehatan: Metode ilmiah penulisan skripsi, tesis dan desertasi. Yayasan Pustaka Obor Indonesia: Indonesia.

Krisnawati H, Kallio M, Kanninen M. 2011. Acacia mangium Willd. Ekologi, Silvikulture dan Produktivitas. CIFOR: Bogor.

Nugroho B. 2004. Ekonomi Keteknikan (Engineering Economic): Analisis Finansial Investasi Kehutanan \& Pertanian. Fakultas Kehutanan Institut Pertanian Bogor : Bogor.

Riyanto, Slamet. 2012. Prakiraan kelayakan finansial pembangunan tegakan jati plus perhutani (JPP) di Kesatuan Pemangkuan Hutan Madiun. Jurnal Ilmu Kehutanan. Volume 6(2): 111-127.

Siswanto. 2007. Operation research Jilid 1. Erlangga: Jakarta.

Sufa, Mila F. 2007. Analisis sensitivitas pada keputusan pembangunan meeting hall untuk minimasi resiko. Jurnal Ilmiah Teknik Industri. Volume 5(3): 97-105. 
Yuniati, Dhany. 2011. Analisis finansial dan ekonomi pembangunan hutan tanaman dipterokarpa dengan teknik silin (studi kasus PT. Sari Bumi Kusuma, Kalimantan Barat). Jurnal Penelitian Hutan Tanaman 8 (4), pp 239-249.

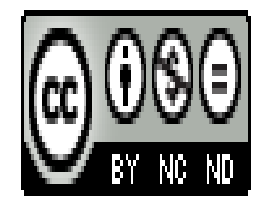

(C) 2019 Wahana Forestra: Jurnal Kehutanan. All rights reserved. This is an open access article distributed under the terms of the BY NC - ND License (https://creativecommons.org/licenses/bync-nd/4.0/). 